Jurnal Indobiosains. Vol 1. No. 2 Edisi Agustus 2019

http://univpgri-palembang.ac.id/e_jurnal/index.php/biosains

\title{
INVENTARISASI DAN IDENTIFIKASI TANAMAN BEKHASIAT OBAT DI KABUPATEN MUSI BANYUASIN SUMATERA SELATAN
}

\author{
Syamsul Rizal ${ }^{1 *}$ dan Sustriana ${ }^{2}$ \\ ${ }^{, 12}$ Program Studi Biologi, Fakultas Matematika dan Ilmu Pengetahuan Alam \\ Universitas PGRI Palembang \\ *e-mail: syamsul_rizal_msi@yahoo.com
}

\begin{abstract}
Research has been carieed out for inventory and identify medicinal plants in the village of Lais, Musi Banyuasin Regency, South Sumatera Province, held in June 2018. This study aims to deterine the types of medicinal plant. Researchis done by exloring the village of Lais. Plants that have been obtanined are inventori and identified. The results of study were obtained 2 classs, 14 orders, 14 families, 17 genera, and 17 species nutrition medicine consists of Andropogon narnus, Curcuma domistica, Zingeber officinale, Pandanus litilis, Citrus aurantifolia, Piper betle, Syzqium polyanthum, Pisidium guajawa, Physalis angulata, Strobilanthes crispus, Orthosipon stamineus, Ocimum santum, Tithonia diversifolia, Jatropha curcas, Trema orientalis, Catharantus roseus, Lansium domesticum.
\end{abstract}

Keywords : Identification, classification, medicinal plants.

\begin{abstract}
ABSTRAK
Telah dilakukan penelitian untuk menginventarisasi dan mengidentifikasi tanaman berkhasiat obat di Desa Lais Kabupaten Musi Banyuasin Provinsi Sumatera Selatan, dilaksanakan pada bulan Juni 2018. Penelitian ini bertujuan untuk mengetahui jenis-jenis tanaman berkhasiat obat. Penelitian dilakukan dengan cara menjelajahi Desa Lais. Tanaman yang telah didapatkan diiventarisasi dan diidentifikasi. Hasil penelitian didapatkan 2 Class, 14 ordo, 14 familia, 17 genus, 17 spesies tanaman berkhasiat obat yaitu : Andropogon narnus, Curcuma domistica, Zingeber officinale, Pandanus litilis, Citrus aurantifolia, Piper betle, Syzqium polyanthum, Pisidium guajawa, Physalis angulata, Strobilanthes crispus, Orthosipon stamineus, Ocimum santum, Tithonia diversifolia, Jatropha curcas, Trema orientalis, Catharantus roseus, Lansium domesticum.
\end{abstract}

Kata kunci: Inventarisasi, identifikasi, tanaman berkhasiat obat 


\section{PENDAHULUAN}

Indonesia dikenal sebagai tempat tumbuhnya tanaman obat sehingga mendapat julukan live laboratory. Sekitar 30.000 jenis tanaman obat dimiliki Indonesia. Dengan kekayaan flora tersebut, tentu Indonesia memiliki potensi untuk mengembangkan produk herbal yang kualitasnya setara dengan obat modern. Akan tetapi, sumber daya alam tersebut belum dimanfaatkan secara optimal bagi kepentingan masyarakat. Baru sekitar 1200 spesies tanaman obat yang dimanfaatkan dan diteliti sebagai obat tradisional. Beberapa spesies tanaman obat yang berasal dari hutan tropis Indonesia justru digunakan oleh negara lain. Sebagai contoh adalah para peneliti Jepang yang telah mempatenkan sekitar 40 senyawa aktif dari tanaman yang ke generasi sekarang, sehingga tercipta berbagai ramuan tanaman obat yang merupakan ciri khas pengobatan tradisional Indonesia. Selain memiliki kekayaan hayati yang besar, pengetahuan masyarakat lokal tentang pemanfaatan sumber daya hayati tersebut cukup tinggi. Oleh karena itu, tidaklah bijaksana apabila pengobatan penyakit dan pemeliharaan kesehatan dengan pemanfaatan tanaman obat tidak diupayakan untuk dikembangkan bagi kepentingan masyarakat dan bangsa (Jhonherf, 2007).

Penggunaan tanaman obat di kalangan masyarakat sangat luas, mulai untuk bahan penyedap hingga bahan baku industri obat-obatan dan kosmetika. Namun, di dalam sistim pelayanan kesehatan masyarakat, berasal dari Indonesia. Bahkan beberapa jenis obat-obatan yang bahan bakunya dapat ditemukan di Indonesia telah dipatenkan dan diproduksi secara besar-besaran di negara lain sehingga memberi keuntungan yang besar bagi negara tersebut (Jhonherf, 2007., Abdullah. 2010).

Mayarakat Indonesia telah mengenal dan memanfaatkan tanaman berkhasiat obat sebagai salah satu upaya untuk menanggulangi masalah kesehatan, jauh sebelum pelayanan kesehatan formal dengan obat-obatan modern dikenal masyarakat. Pengetahuan tentang pemanfaatan tanaman obat tersebut merupakan warisan budaya bangsa berdasarkan pengetahuan dan pengalaman yang diwariskan secara turun-temurun hingga kenyataannya peran obat-obat alami belum sepenuhnya diakui, walaupun secara empiris manfaat obat-obat alami tersebut telah terbukti. Sebagai salah satu contoh adalah penggunaan jamu sebagai obat kuat, obat pegal linu, mempertahankan keayuan, pereda sakit saat datang bulan dan lain-lain, mengisyaratkan penggunaan jamu yang sangat luas di masyarakat. Memang disadari, bahwa produksi jamu belum banyak tersentuh oleh hasil-hasil penelitian karena antara lain disebabkan para produsen jamu pada umumnya masih berpegang teguh pada ramuan yang diturunkan turun-temurun. Dampaknya, hingga saat ini obat tradisional masih merupakan bahan pengobatan alternatif selain obat modern. Hal ini bisa membuka 
peluang bagi pengusaha atau petani tanaman obat untuk menjadikan ramuan obat tradisional nya menjadi Semakin tinggi biaya pengobatan dan harga obat-obatan kimia, serta banyaknya efek samping yang ditimbulkan dari mengkonsumsi obat-obatan kimia, sudah saatnya masyarakat lebih mengenal dan memanfaatkan kembali tanaman berkhasiat obat. Hal ini dikarenakan kekhawatiran masyarakat terhadap efek samping dalam mengkonsumsi obat obatan berbahan kimia. Di samping itu dikarenakan tingkat kebutuhan masyarakat terhadap pengobatan semakin besar sementara kemampuan ekonomi masih rendah, maka pengobatan dengan memanfaatkan bahan alam yang ekonomis merupakan solusi yang baik untuk menanggulangi masalah tersebut (Suriawiria, 2000., Agoes, Azwar. 2010).

Di Provinsi Sumatera Selatan yang terdiri dari 15 Kabupaten/kota memiliki tanaman berkhasiat obat yang dapat dijadikan bahan ramuan obat atau jamu. Karena Sumatera Selatan juga sebagai salah satu Provinsi yang mempunyai kekayaan tumbuhan hayati yang dapat dikembangkan menjadi industri obat tradisional, seperti yang juga telah dilakukan oleh daerah lainnya di Indonesia. Salah satunya adalah Desa lais Kecamatan Musi Banyuasin. Desa ini merupakan gerbang utama ketika memasuki wilayah Musi Banyuasin dari arah Palembang. Desa ini berdasarkan komoditas pertaniannya adalah tanaman pangan seperti padi, jagung kacangkacangan, sayur-sayuran serta tanaman buah-buahan seperti durian, bahan pengobatan primer, tidak hanya sebagai alternatif (Maheshwari, 2002., Prasetyo. 2012). duku, manggis dan mangga. Sebagian lagi lahan dimanfaatkan sebagai lahan untuk perkebunan seperti menanam karet, sawit dan kelapa. Serta lahan tersebut juga dimanfaatkan untuk peternakan seperti berternak ayam, bebek, burung, sapi dan domba serta kambing.

Lahan dan pekarangan rumah yang masih luas mendorong masyarakat untuk berinspirasi memperindah lingkungan dengan menanam tanaman disekitar rumah mereka. Sehingga dengan banyaknya tanaman di Desa Lais ini diperkirakan memiliki tanaman berkhasiat obat dengan berbagai jenis. Khasiat dari setiap bagian tanaman kemungkinan belum semua orang mengetahuinya, walaupun jenis tanaman secara umum sudah diketahui. Oleh karena itu perlu dilakukan inventarisasi dan identifikasi jenis-jenis tanaman berkhasiat obat yang terdapat pada Desa Lais Kabupaten Musi Banyuasin Provinsi Sumatera Selatan.

\section{BAHAN DAN METODE}

Penelitian ini menggunakan metode deskriptif yang dilaksanakan dari bulan April Sampai dengan bulan November 2018 di desa Lais, Kabupaten Musi Banyuasin Provinsi Sumatera Selatan. Identfikasi hasil penelitian dilakukan di Laboratorium Science Center Universitas PGRI Palembang.

Bahan yang digunakan dalam penelitian ini koran, kertas, karton putih, kertas label, isolatif, kantong 
plastik, spesimen tumbuhan berkhasiat obat yang didapat dan alkohol $70 \%$. Alat yang digunakan berupa pisau, botol, sprayer, gunting tanaman dan alat tulis.

Penelitian ini menggunakan metode penjelajahan secara vertical di area pemukiman penduduk di desa Lais Kabupaten Musi Banyuasin Sumatera Selatan. Data yang diperoleh dianalisis secara deskriftif dan hasil yang diperoleh ditampilkan dalam bentuk tabel.

Pelaksanaan penelitian ini terdiri dari beberapa tahap meliputi penentuan lokasi penelitian, pengambilan specimen tumbuhan berkhasiat obat, inventarisasi, pemotretan specimen tumbuhan berkhasiat obat, pembuatan deskripsi, identifikasi tumbuhan, pembuatan herbarium.

\section{Penentuan Lokasi Penelitian}

Lokasi penelitian di desa Lais, Kabupaten Musi Banyuasin Provinsi Sumatera Selatan.

Pengambilan Spesimen Tumbuhan Berkhasiat Obat

Pengambilan specimen tumbuhan berkhasiat obat dilakukan dengan menjelajahi area pemukiman penduduk. Tumbuhan yang diperoleh diambil satu dari jumlah yang ada dari masing-masing spesies tumbuhan berkhasiat obat tersebut. Tumbuhan tersebut dimasukkan ke dalam kantong dan disemprot dengan alkohol $70 \%$

Inventarisasi

Inventarisasi dilakukan dengan menghitung jenis tumbuhan yang diperoleh di desa Lais Kabupaten Musi Banyuasin Provinsi Sumatera Selatan.

\section{Pemotretan Specimen Tumbuhan Berkhasiat Obat}

Tujuan dari pemotretan specimen adalah untuk mendapatkan gambaran lengkap mengenai tempat tumbuh serta ciri-ciri, baik warna serta morfologi tumbuhan berkhasiat obat.

\section{Pembuatan Deskripsi}

Dari setiap jenis tumbuhan paku yang ditemukan, maka dibuatkan suatu koleksi khusus secara lengkap dengan bagian-bagian yang dimilikinya serta mencatat kondisi tumbuhan paku secara langsung dalam keadaan yang masih segar di alam, hingga diperoleh data lengkap tentang suatu jenis tumbuhan.

\section{Identifikasi Tumbuhan}

Identifikasi tumbuhan

dilakukan dengan cara menggunakan kunci determinasi tumbuhan berkhasiat obat. Tumbuhan yang diamati diamati bagian-bagian tubuhnya dalam kondisi masih segar.

\section{Pembuatan Herbarium}

\begin{tabular}{lr}
\multicolumn{2}{c}{ Pembuatan herbarium } \\
dilakukan dengan
\end{tabular} membersihkan tumbuhan tersebut dari kotoran-kotoran yang melekat, lalu tumbuhan tersebut dimasukkan ke dalam kantong yang telah disemprot alkohol 70\%. Setelah itu tumbuhan dibentangkan dan disusun rapi di dalam kertas karton tebal, lalu dikeringkan di bawah sinar matahari sampai tumbuhan tersebut kering. Tumbuhan yang telah kering selanjutnya diolesi alkohol $70 \%$, lalu ditempelkan pada karton putih dengan menggunakan solatif. Kemudian tempelkan lebel yang berisi deskripsi, sistematika dan autornya, lalu tutup herbarium 
dengan menggunakan plastik transparan.

HASIL DAN PEMBAHASAN Keragaman Tumbuhan Berkhasiat Obat

Dari hasil penelitian yang telah dilakukan di Desa Lais,
Kecamatan Musi Banyuasin Sumatera Selatan didapatkan 17 spesies tanaman berkhasiat obat yang terdiri dari, 2 class, 14 ordo, 14 famillia, dan 17 genus. Komposisi tanaman berkhasiat obat di tampilkan pada tabel 1 berikut.

Tabel 1. Hasil inventarisasi dan identifikasi tanaman berkhasiat obat di Desa Lais Kecamatan Musi Banyuasin Provinsi Sumatera Selatan

\begin{tabular}{|c|c|c|c|c|c|c|}
\hline No & Class & Ordo & Famillia & Genus & Spesies & Nama local \\
\hline 1 & $\begin{array}{l}\text { Monocotyle } \\
\text { doneae }\end{array}$ & Poales & Poaceae & Andropogon & Andropogon narnus & Serai \\
\hline 2 & & & & Curcuma & Curcuma domistica & Kunyit \\
\hline 3 & & Zingeberales & Zingeberaceae & Zingerber & Zingeber officinale & Jahe \\
\hline 4 & & Pandanales & Pandanaceae & Pandanus & Pandanus litilis & Pandan \\
\hline 5 & $\begin{array}{l}\text { Dicotyledo } \\
\text { neae }\end{array}$ & Rutales & Rutaceae & Citrus & Citrus aurantifolia & Jeruk nipis \\
\hline 6 & & Piperales & Piperaceae & Piper & Piper betle & Sirih \\
\hline 7 & & Myrtales & Myrtaceae & Syzqium & Syzqium polyanthum & Daun salam \\
\hline 8 & & & & Psidium & Pisidium guajawa & Jambu biji \\
\hline$\Omega$ & & Solanales & Solanaceae & Physalis & Physalis angulata & Ciplukan \\
\hline 10 & & $\begin{array}{l}\text { Scrophularial } \\
\text { es }\end{array}$ & Scrophulariaceae & Stobilanthes & Strobilanthes crispus & Keji beling \\
\hline 11 & & Lamiales & Lamiaceae & Orthosipon & Orthosipon stamineus & Kumis kucing \\
\hline 12 & & & & Ocimum & Ocimum santum & Kemangi \\
\hline 13 & & Asterales & Asteraeceae & Tithonia & Tithonia diversifolia & Insulin \\
\hline 14 & & Euphorbiales & Eurphorbiaceae & Jatropha & Jatropha curcas & Jarak \\
\hline 15 & & Urticales & Urticaceae & Trema & Trema orientalis & $\begin{array}{l}\text { Daun seribu } \\
\text { obat } \\
\text { (anggrung) }\end{array}$ \\
\hline 16 & & Gentianales & Apocynaceae & Catharantus & Catharantus roseus & $\begin{array}{l}\text { Daun katarak } \\
\text { (tapak dara) }\end{array}$ \\
\hline 17 & & Sapindales & Meliaceae & Lansium & Lansium domesticum & Duku \\
\hline
\end{tabular}


Berdasarkan jenis-jenis tanaman berkhasiat obat di atas yang didapatkan dalam 1 divisio yaitu Spermathophyta. Divisio Spermathophyta terdapat 2 Class yaitu Dicotyledonea dan Monokotyledoneae.

\section{Andropogon nardus L.}

Tumbuhan menahun, membentuk jerami. Batang bulat cylindris atau beraturan pada satu sisi. Pelepah daun gundul, malai tegak, cabang utama dalam karangan. Tumbuhan berbatang basah, tingginya sampai $0,75 \mathrm{~m}$, daunnya berbentuk lonjong, bunga majemuk berwarna merah atau merah muda. Tanaman herba tahunan ini menghasilkan umbi utama berbentuk rimpang berwarna kuning tua atau jingga terang. Perbanyakannya dengan anakan, di Indonesia dikenal dengan nama serai.

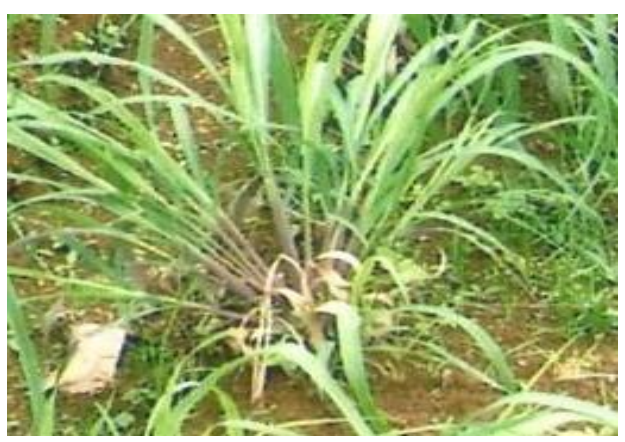

Gambar 1. Andropogon nardus L

\section{Curcuma domistica L.}

Tumbuhan berbatang basah, tingginya sampai $0,75 \mathrm{~m}$, daunnya berbentuk lonjong, bunga majemuk berwarna merah atau merah muda. Tanaman herba tahunan ini menghasilkan umbi utama berbentuk rimpang berwarna kuning tua atau jingga terang. Perbanyakannya dengan anakan, di Indonesia dikenal dengan nama kunyit.

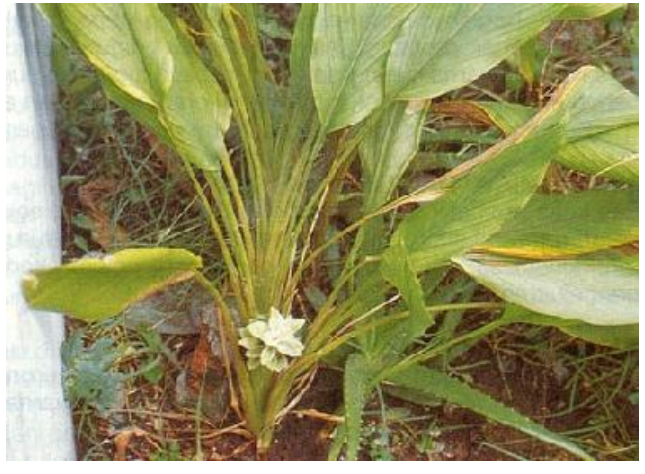

Gambar 2. Curcuma domistica L.

\section{Zingiber officinale}

Tanaman ini bisa bertahan hidup di daerah tropis dan dikenal memiliki rasa pedas dan hangat pada rimpangnya. Tanaman sejenis herba, tumbuh tegak dengan ketinggian pohon antara 30-60 $\mathrm{cm}$. Batang pohon semu, beralur dan memiliki warna hijau.

Bunga berupa malai tumbuh dari dalam tanah berbentuk tongkat atau bundar telur, panjang malai berkisar antara3,5-5 cm dengan lebar 1,5-1,75 cm. Buah berbentuk bulat hingga bulat panjang, berwarna coklat sedang biji berbentuk bulat dengan warna hitam.

Zingiber officinale merupakan salah satu tanaman berupa tumbuhan rumpun berbatang semu. Jahe adalah tanaman rimpang yang sangat populer dikalangan masyarakat baik sebagai bahan rempah dapur ataupun bahan obat.

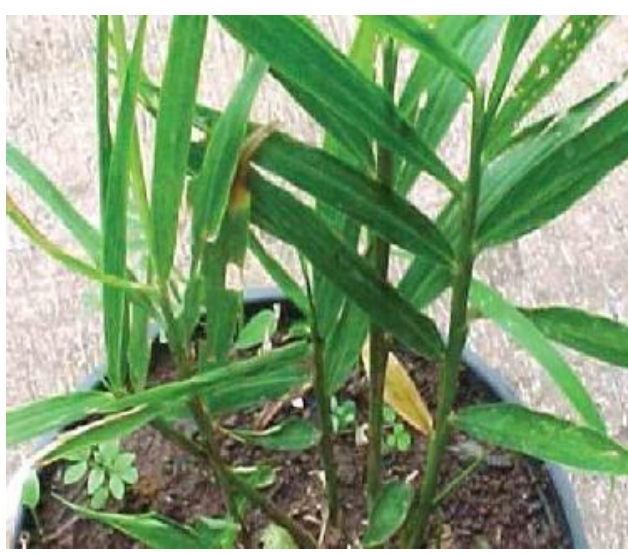

Gambar 3. Zingiber officinale 


\section{Pandanus litilis}

Akar tanaman ini berserabut, akar tunjang yang menopang pada tanaman lainnya, perakaran ini memiliki panjang mencapai 30-60 cm bahkan lebih, berwarna kecokalatan dan juga dapat mencapai kedalaman tanah $30 \mathrm{~cm}$.

Batang tanaman daun menjalar, berbentuk bulat, lunak, bercabang dan juga dapat mencapai 2 meter bahkan lebih. Pandanus litilis adalah berdaun bercabang lebar dan memanjang dan berbatang banyak. Bunga daun pandan ini merupakan bunga yang majemuk, bebentuk dalam tandan atau tongkol yang berwarna putih. Bunga ini terletak pada ketiak daun pelindung dan juga terletak di sekitar ujung bagian batang. Bunga ini biasanya dapat menyerbuk dengan alami maupun dengan bantuan hewan sekitar, dikenal dengan Pandan wangi.

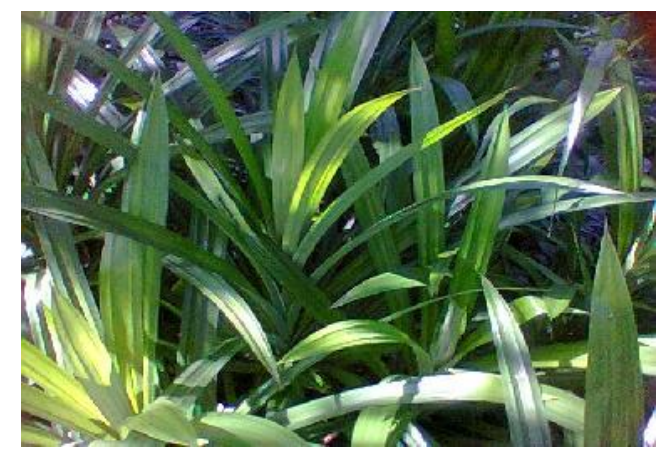

Gambar 4. Pandanus litilis

\section{Citrus aurantifolia}

Pohon yang bercabang banyak, 1,5-3,5 $\mathrm{m}$. duri $0,3-1,2 \mathrm{~cm}$ panjangnya. Tangkai daun kearah ujung kadangkadang bersayap sedikit, sayap beringgit melekuk ke dalam, panjang 0,5- 2,5 cm. helaian daun bulat telur elliptis atau bulat telur memenjang, dengan pangkal bulat dan ujung tumpul, melekuk ke dalam sedikit, tepi beringgit, panjang2,5-9 $\mathrm{cm}$. bunga 1,5-2,5 $\mathrm{cm}$ diameternya. Daun mahkota dari luar putih kuning.

Pohon yang bercabang banyak. Tangkai daun kea rah ujung kadang- kadang bersayap sedikit. Daun berhadapan atai berseling, tunggal atau majemuk, dengan kelenjar minyak yang transparan.

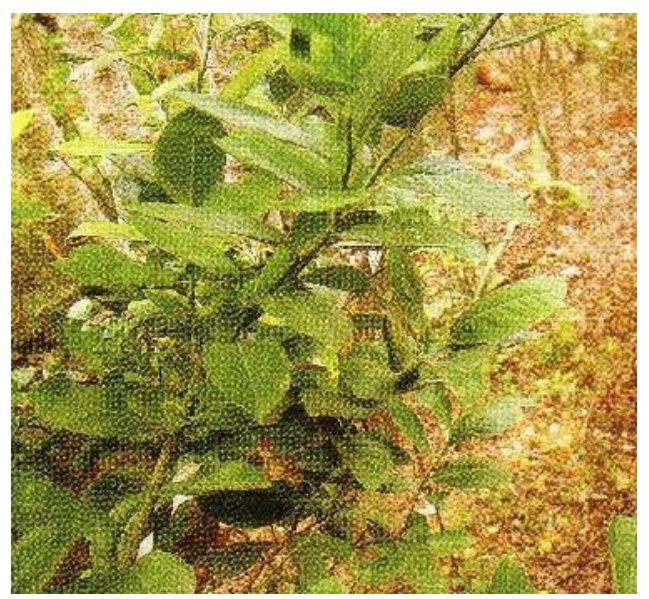

\section{Gambar 5. Citrus aurantifolia}

\section{Piper Betle}

Tumbuhan memanjat, ruas batang terlihat jelas. Semak atau perdu jarang pohon. Bunga kecil, dalam bulir. Yang terahir kadang-kadang keseluruan nya berbentuk paying.

Tumbuhan memanjat, batang panjang 5-15 meter. Daun berseling atau bersebar, bertangkai, daun penumpuk cepat rontok, dan meninggalkan tanda bekas berbentuk cincin. Helain daun bulat telur sampai memanjang, dengan pangkal daun berbentuk jantung.

Piper belte adalah tanaman memanjat, dengan ruas batang terlihat jelas. Daun duduknya berbeda, helaian daun bulat telur sampai memanjang.

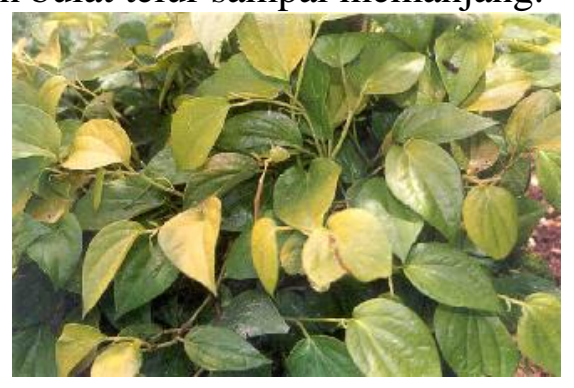

Gambar 6. Piper beltle 


\section{Syzqium polyanthum}

Berdaun berhadapan, berseling atau sejajar, tapi rata, dengan kelenjar minyak (dapat dilihat dengan cahaya menembus). Dengan bunga beraturan.

Pohon atau perdu tegak. Daun berhadapan, bunga beraturan kerapkali berkelamin 2,berjumla 4-5. Daun pelindung kecil, kelopak, berdaun lekat tabung kerapkali di atas bakal buah diperpanjang, tepi kadang-kadang sebelum mekar rontok seperti tudung. Taju 3-5, daun mekar. Benang sari umum nya banyak.

Buah buni berbiji banyak. Bagian mudah berambut. Tabung kelopak tidak atau sedikit sekali diperpanjang di atas bakal buah,tepi kelopak sebelum mekar berlekatan menjadi bentuk cawan, kemudian membelah menjadi 2-5 taju yang tidak sama. Buah buni berbiji 1-6, kebanyakan berbiji 1. Juga bagian mudah gundu. Tabung kelopak di perpanjang di atas bakal buah, tepi kelopak dalam stadium kuncup dengan taju berbeda atau gigi kecil.

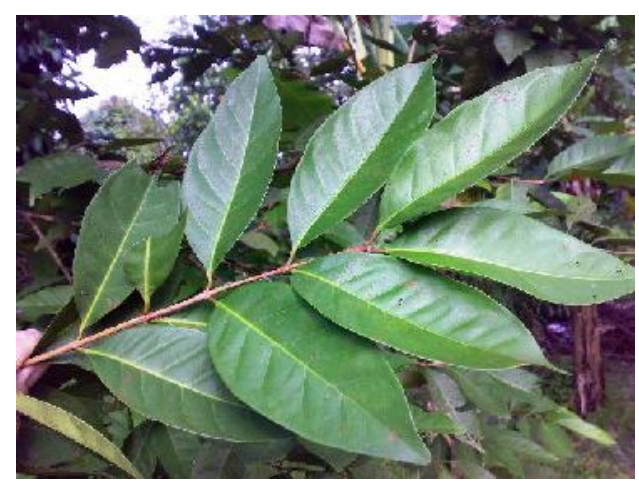

Gambar 7. Syzqium polyantum

\section{Psidium guajava}

Digolongkan ke Perdu atau pohon kecil, tinggi 3-10 m. kulit perak, licin, terkelupas dalm potongan. Ruas tangkai teratas segiempat tajam. Daun muda berbuluh abu-abu. Daun bertangkai pendek, bulat panjang atau memanjang, 6-14 kali 1-3 tangkai $1-4 \mathrm{~cm}$. tabung kelopak berbentuk lonceng atau corong, panjang $0,5 \mathrm{~cm}$, pinggiran tidak rontok.

Psidium guajava adalah daun mahkota berbentu bulat telur terbalik. Benang sari pada tonjolan dasar bunga yang berbulu. Buah buni bundar, bentuk "peer" atau bentuk telur terbalik.

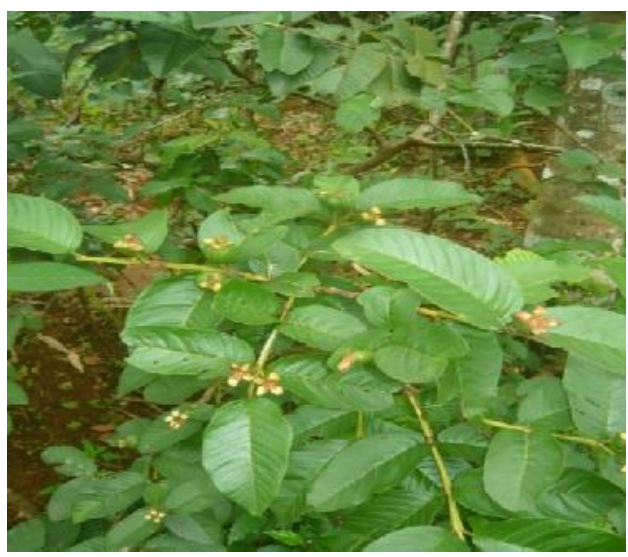

Gambar 8. Psidium guajava

\section{Physalis angulata}

Merupakan jenis rumput rumputan yang lemas dengan bunga berbentuk bintang berwarna kuning, tidak pahit. Daun dengan kelanjar halus berwarna kuning. Duah berwana kemerahan. Digolonkan herba 1 tahun, tegak, tinggi $0,1-1 \mathrm{~m}$. bagian yang hijau berrambut pendek atau boleh dikatakan gundul. Batang berusuk bersegi tajam, terongga. Helain daun bulat telur menjang bentuk lenset, dengan ujung runcing, bertepi rata atau tidak, 5-15 kali 2,5-10,5 cm. tangkai bunga tegak dengan ujung yang mengangguk, langsing, lembayung, 8-23 mm.

Batang berusuk bersegi jatam, berongga, berakar tunggal. Physalis angulata tergolong kedalam tanaman yang tegak yang hidup di kebun, tegalan, pinggir jalan, semak, hutan ringan, tepi hutan, gunduk. 


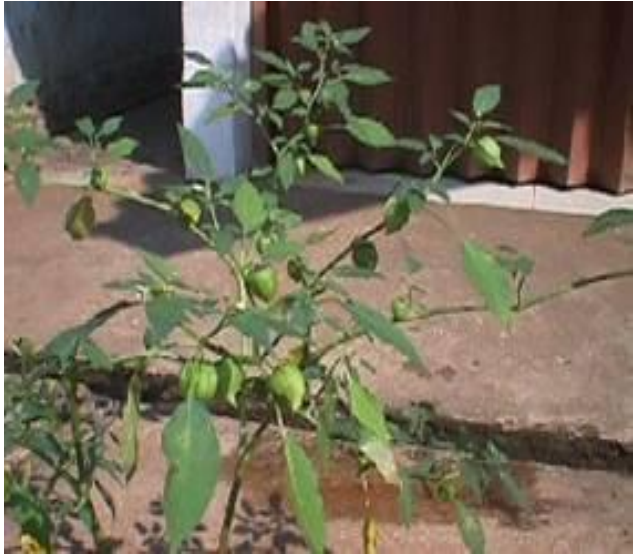

Gambar 9. Physalis angulata

\section{Strobilanthes crispus}

Tanaman terna. Batang beruas, bentuk bulat, berbulu Kasar, percabangan monopodial, hijau. Daun tunggal, berhadapan, lanset atau lonjong, tepi beringgil, ujung meruncing, pangkal runcing, panjang 9-18 cm, lebar 3-8 cm, bertangkai pendek, pertulangan menyirip, hijau. Bunga majemuk, bentuk bulir.

Daun tunggal, berhadapan, lanset atau lonjong, tepi beringgil, ujung meruncing, pangkal runcing. Daun

berbentuk lonjong dan berwarna hijau, permukaan daun bila diraba terasa kasar karena terdapat rambut-rambut halus. Begitu pula batang atasnya yang juga berambut halus. Sistem perakarannya berupa akar tunggang. Tangkai daun berwarna ungu dan merupakan tangkai yang mudah untuk mengenal tanaman ini. Tepi daun muda berwarna ungu dan bergerigi, ujung daun lancip. Buku-buku batangnya agak menggelembung dan berwarna keunguan, seolah-olah berkelenjar. Batang memiliki banyak cabang yang tumbuh sangat dekat dengan tanah. Akar tunggang coklat muda, tangkai daun berwarna ungu dan tepi berigi. Spesies yang termasuk kedalam golongan ini mudah berkembangbiak pada tanah subur, agak terlindung dan di tempat terbuka.

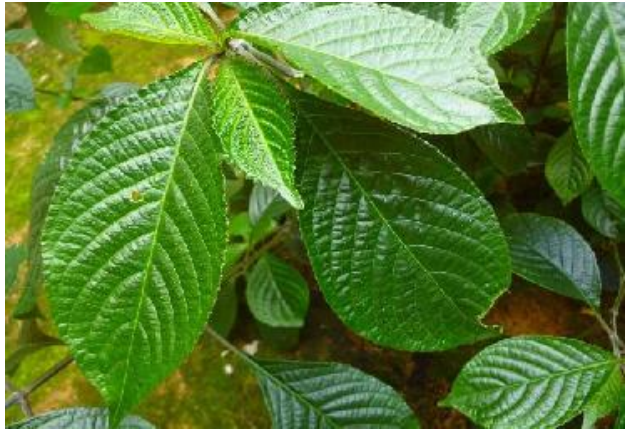

Gambar 10. Strobilanthes crispus

\section{Orthosiphon staminues}

Ukuran daun panjang $1-10 \mathrm{~cm}$ .Urat daun sepanjang pinggir berbulu tipis atau gundul, dimana kedua permukaan berbintik-bintik karena adanya kelenjar yang jumlahnya sangat banyak. Batang bersegi empat agak beralur berbulu pendek atau gundul.

Tingginya mencapai 2 meter. Batang bersegi empat agak beralur berbulu pendek atau gundul. Helai daun berbentuk bundar atau lojong, lanset, bundar telur atau belah ketupat yang dimulai dari pangkalnya. Ukuran daun panjang 1 $10 \mathrm{~cm}$ dan lebarnya $7.5 \mathrm{~mm}-1.5 \mathrm{~cm}$.

Benang sari menjulang lebih dari $2 \mathrm{~cm}$ di luar mahkota. Kepalah putik bentuk tombol, berlekuk 2 di dalam mahkota lila sangat pucat. Benang sari tidak pernah menjulang sedemikian jauh, kepala putik terbelah. Mahkota berwarna lain.

Herba berkayu naik berlahanlahan, pada pangkal sering bercabang, di sana berakar kuat, tinggi 0,4-1,5 m. Batang berambut pendek. Tangkai daun 0,4-3 cm. Helain daun bulat telur, elliep atau memanjang, dengan pangkal berbentuk baji, di atas pangkal yang bertepi rata bergigi kasar, dapat di katakana gundul.2- 10 kali $1-5 \mathrm{~cm}$, karangan daun berlindung kecil. Tangkai bunga pendek.

Batang berambut pendek, helaian daun berbentuk bulat telur, ellips atau 
memanjang dengan akar berbentuk baji.

Tumbuh tegak, tinggi $0,4-5 \mathrm{~m}$. Batang berambut pendek, helaian daun bulat telur. Daun pelindung kecil, tangkai bunga pendek. Kelopak bermbut pendek, taju atau hampir sampai pangkal tabung berahir dengan 2 rusuk.

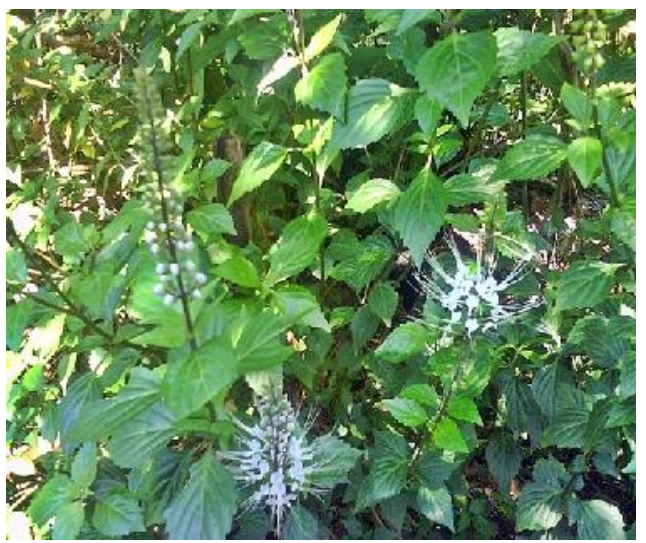

Gambar 11 . Orthosiphon staminues

\section{Ocimum sanctum}

Herba tegak, sangat harum tinggi 0,3-0,6 m. Batang sering keunguan, caranya berambut berubah- ubah. Tangkai daun 0,5-2 cm, helaian dau bulat telur ellips, ellips atau memanjang, daun bar 12. Ocimum sanctum

\section{Jatropha curcas}

Pohon, perdu semak, kadangankadang berair, kerapkali mengandung getah. Daun tersebar, kadang-kadang berhadapan, tunggal, atau majemuk menjari, kerapkali dengan daun penumou. Ujung tangkai daun atau pangkal helaian daun kerapkali dengan kelenjar. Bunga berkelamin 1, berumah 1 atau 2 bunga betina dan jantan kadangkadang berbeda besar, kadang- kadang tersusun dalam. Tenda bunga tunggal atau rangkap, kadang-kadang tidak ada. Tonjolan menebal, dasar bunga kerapkali ada. Benang sari 1 sampai banyak. Lepas atau melekat. Bakal buah menumpag,
Spesies Orthosipon stamineus

ujung runcing, berbintingk-bintik serupa kelenjar.

Batang berwarna keunguunguan, berambut berubah ubah. Ocimum sanctum herba tegak, sangat harum. Batang keunguan berambut berubah-ubah tangkai daun 0,5-2 cm. helaian daun bulat telur, memanjang, dengan ujung runcing, berbintik-bintik serupa kelnjar.

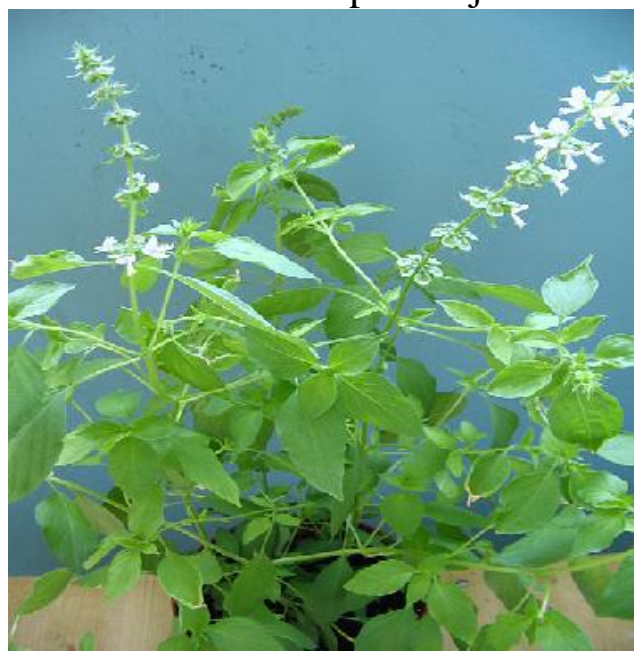

Gam

beruang 2-4 biji 1-2 beruang. Buah bermacam-macam.

Tangkai daun dan tepi daun gundul. Benang sari ada 10. Jatropha curcas adalah tanaman yang bergetah, memiliki batang bulat dan helaian bulat, daun tersebar, kadang- kadang berhadapan, tunggal atau majemuk menjari.

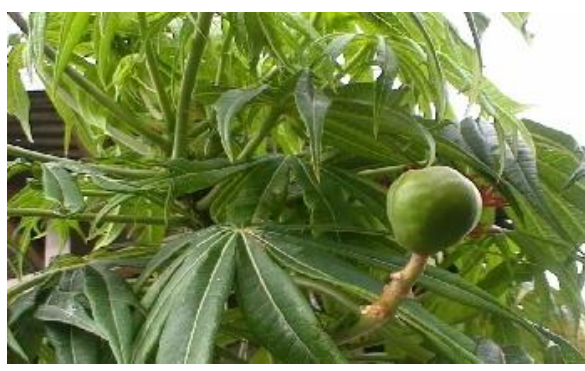

Gambar 13 . Jatropha curcas 


\section{Tithonia diversifolia}

Tumbuhan ini adalah berdaun tunggal berbatang kayu tegak berakar tunggang duduk daun folia oposita berdaun lebar bulat telur bertulang daun menyirip posisi tulang-tulang cabang tersusun dari sebelah kiri dan kanan ibu tulang daun daging tipis seperti selaput daun mudah sekali robek berbunga majemuk.

Daun bertangkai, bangun bulat telur, berangsur runcing hingga pangkal. Perdu yang tegak, yang bertunas dalam anah, 1-3 m tinggi batang. Batang bulat, dengan empelur putih, dekat pangkal setiap daun dengan 2 daun penumpu oval melintang dari max. $2 \mathrm{~cm}$ panjangnya. Daun bertangkai, bungan bulat telur, berangsur runcing hingga pangkal. Berlekuk 3-5 dangkal hingga dalam atau bercangap 3-5, berrigi, berambut dan meruncing tajam.

Batang bulat, daun bertangkai, dengan bangun bulat telur berangsur runcing. Tithonia diversifolia adalah tanaman tegak yang bertunas dalam tanah. Tinggi 1-3 meter. Batang bulat dengan empelur putih. Dasar bunga bersama bentuk kerucut lebar, sisik jerami $1 \mathrm{~cm}$ panjangnya. Bunga tepi ik 13, mandul, tabung berambut rapat.

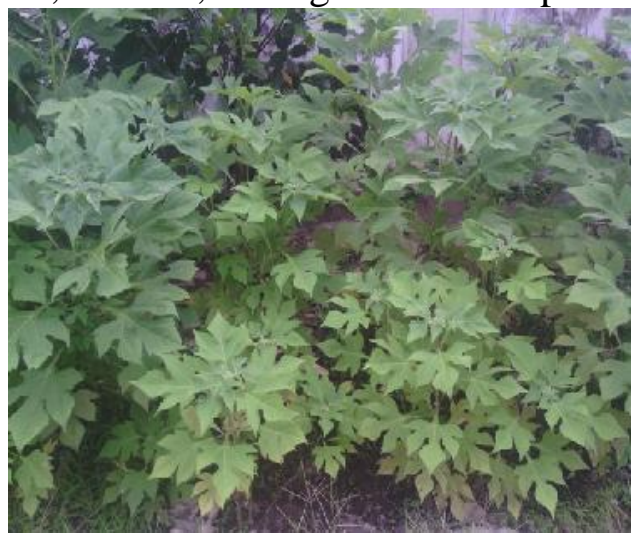

Gambar 14 . Tithonia diversifolia
Tumbuhan berbentuk pohon, berumur menahun (perenial), tinggi sekitar $10 \mathrm{~m}$. Akar tunggang. Batang aerial, berkayu, silindris, tegak, warna hitam kecokelatan, permukaan halus, percabangan simpodial (batang utama tidak tampak jelas). Daun majemuk, bertangkai, tersusun selang-seling (alternate), warna hijau, panjang $5-9 \mathrm{~cm}$, lebar 2,5 - 3,5 cm, bentuk lonjong, ujung runcing (acutus), pangkal tumpul (obtusus), tepi rata (tidak bergerigi), pertulangan menyirip (pinnate) Bunga majemuk, muncul dari ketiak daun (axillaris), panjang mahkota $0,5 \mathrm{~cm}$ Buah buni (bacca), warna buah muda hijau setelah tua menjadi cokelat, berisi 4-10 dengan biji Perbanyaan Generatif (biji).

Daun majemuk, berseling, lonjong, tepi rata, ujung runcing, pangkal tumpul, pertulangan menyirip, tangkai silindris.

Trema orientalis adalah daun majemuk, panjang berseling dengan tepi rata. Batang tegak, silindris, berkayu, permukaan halus, percabangan simpodial, hitam kecoklatan.

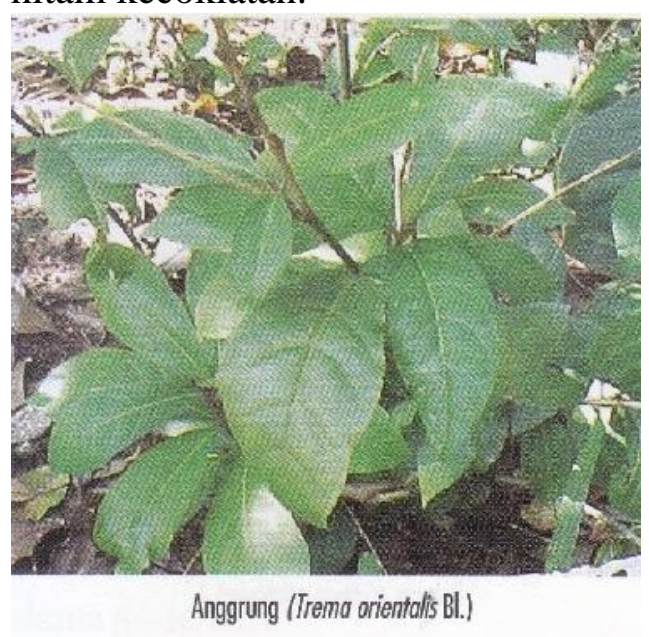

Gambar 15. Trema orientalis

\section{Catharantus roseus}

Tapak dara (Catharanthus roseus) merupakan tanaman herba/semak yang tegak, hidup lama, tinggi 0,2-0,8 $\mathrm{m}$ dan mengandung getah. Batangnya mengandung getah berwarna putih susu, 
berbentuk bulat dengan diameter berukuran kecil, berkayu, beruas, bercabang, dan berambut sangat lebat. Batang berbentuk bulat dengan diameter berukuran kecil, berkayu, beruas, bercabang.

Tanaman ini bisa mencapai 0,2-1 meter. Memiliki batang yang berbentuk bulat dengan diameter berukuran kecil,berkayu, beruas, dan bercabang serta berambut. Daunnya berbentuk bulat telur, berwarna hijau, tersusun menyirip berselingan dan diklasifikasikan berdaun tunggal. Panjang daun sekitar 2-6 cm, lebar 1-3 cm, dan tangkai daunnya sangat pendek. Bunganya aksial (muncul dari ketiak daun). Kelopak bunga kecil, berbentuk paku. Mahkota bunga berbentuk terompet dengan permukaan berbulu halus, ujungnya melebar, berwarna putih, biru, merah jambu atau ungu tergantung kultivarnya.

Batang yang berbentuk bulat dengan diameter berukuran kecil, berkayu, beruas, dan bercabang serta berambut. Catharantus roseus adalah tanaman berdaun berbentuk bulat telur, berwarna hijau, tersusun menyirip berselingan dan diklasifikasikan berdaun tunggal. Batang yang berbentuk bulat.

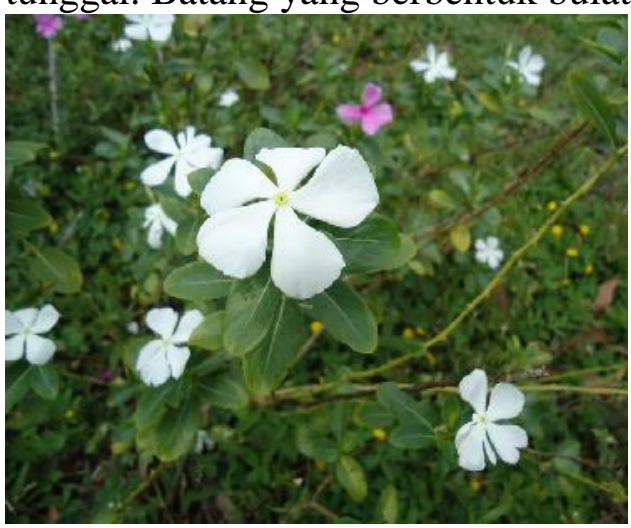

Gambar 16. Catharantus roseus

\section{Lansium domesticum}

Tanaman ini batang berkayu (keras), Pada permukaan batang duku terdapat bintik bintik berwarna coklat. Batang berwarna abu-abu, berbentuk silindris, percabangan monopodial yaitu antara batang induk dengan cabang terlihat jelas dari perbedaan ukurannya, arah tumbuh batang tegak lurus dan arah tumbuh cabang condong ke atas.

Pohon dengan tinggi 1-20 meter. Buah tanaman ini rasanya sangat manis, kenyal, dan memiliki kandungan air yang cukup banyak. Bentuknya bulat atau bulat memanjang (bulat buni) dengan diamter 2 sampai $4 \mathrm{~cm}$, kulit buah duku muda berwarna hijau dan berubah menjadi kuning setelah buah masak. Daging buahnya tebal, kenyal dan buahnya melapisi bijinya.

Tulang daunnya menyirip, pada bagian permukaan atas daunnya mengkilat, ujung daunnya meruncing pendek, tepi daun rata. Lansium domesticum, merupakan tanaman buah berupa pohon yang berasal dari Indonesia. Memiliki daun yaitu memiliki helaian daun (lamina), Tangkai daun (petiolus), dan Upih daun atau pelepah daun (vagina). Daunnya berwarna hijau.

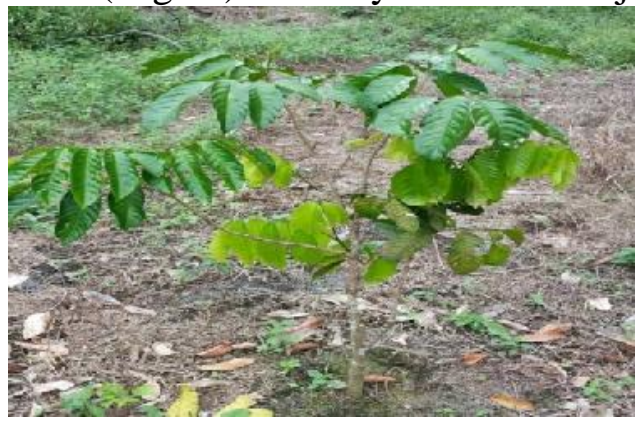

Gambar 17. Lansium domesticum

\section{KESIMPULAN}

Berdasarkan hasil penelitian yang telah dilakukan di Dusun IV Desa Lais Kecamatan Lais Kabupaten Musi Banyuasin ditemukan jenis-jenis tumbuhan obat yang berasal dari 2 Class, 14 ordo, 14 familia, 17 genus, 17 spesies yaitu: Andropogon narnus, Curcuma domistica, Zingeber officinale, Pandanus litilis, Citrus aurantifolia, Piper betle, Syzqium polyanthum, Pisidium guajawa, Physalis angulata, Strobilanthes crispus, Orthosipon stamineus, Ocimum santum, Tithonia diversifolia, Jatropha curcas, 
Trema orientalis, Catharantus roseus, Lansium domesticum. Bagian-bagian dari jenis-jenis tumbuhan obat yang dimanfaakan sebagai bahan baku berkhasiat obat tradisional class monocotyledoneae dan dicotyledoneae yaitu: daun, batang, akar/rimpang, buah, biji, bunga, kulit, dan getah, dengan khasiat yang beraneka ragam.

\section{SARAN}

Perlu adanya penelitian yang lebih lanjut dalam rangka pembudidayaan tanaman obat sebagai alternatif lain dalam pengobatan dan untuk kelestariannya. Serta perlu dilakukan penelitian terhadap kandungan kimia dan efek farmakologis yang terdapat pada jenis tanaman obat yang sudah ada maupun yang belum diketahui.

\section{DAFTAR FUSTAKA}

Abdullah. 2010. Inventarisasi Jenis-Jenis Tumbuhan Berkhasiat Obat Di Hutan Dataran Rendah Desa Nyamplung Pulau Karimun Jaya. Dalam jurnal of Biosaintifikasi. Vol.2.No.2, Maret 2016.

Abednego, Bangun. Ensiklopedia Tanaman Obat Indonesia. Bandung: Indonesia Publishing House, 2012.

Agoes, Azwar. 2010. Tanaman Obat Indonesia. Jakarta: Salemba Medika.

Gunarto. 1999. Tanaman Obat Tradisional. Dalam Jurnal Mandiri Tumbuhan Obat.akses 02 Maret 2016).

Jhonherf, 2007. Pemanfaatan Tanaman Obat. Dalam Jurnal USU Institutional Repository.akses 02 Maret 2016

Maheswari, 2002. Pemanfaatan Tanaman Herbal. (http://eprints.unlam.ac.id/188/1/ Mandiri Tumbuhan Obat.akses 02 Maret 2016).

Suriawiria. Pengembangan Obat Alami Berdampak Positif. Jakarta. 2000

Prasetyo. 2012. Defenisi Tanaman Obat Keluarga (TOGA). Dalam, Ekowati R, Nuryanto, Salmah. Pemanfaatan Tanaman Obat di Sumatera Selatan. Kharisma Putra Utama Offeset, 2013. 